\title{
INFLUENCE OF THE NATURE OF TRANSITION METAL ON ACID-BASE PROPERTIES OF THE SURFACE AND ACTIVITY OF CATALYSTS BASED ON NATURAL CLINOPTILOLITE IN THE REACTION OF BIOGAS CONVERSION TO SYNTHESIS GAS
}

\author{
S.T.Jafarova \\ M.Nagiev Institute of Catalysis and Inorganic Chemistry, NAS of Azerbaijan \\ rsevil7@gmail.com
}

Received 12.10.2020

Accepted 14.12.2020

\begin{abstract}
Catalysts based on natural clinoptilolite modified by transition metals ( $\mathrm{Ni}, \mathrm{Co}, \mathrm{Cr}, \mathrm{Mo}, \mathrm{Fe}$ ) were studied in the reaction of biogas conversion to synthesis gas. A particular attention is paid to exposing of relationship between acid-base properties surface - activity. This was achieved by studying the effect of the introduced transition metal nature on the acid-base spectrum and comparing the data obtained with sample activity. The highest activity and selectivity of the nickel sample has been established, that makes it possible to achieve complete methane conversion at $700^{\circ} \mathrm{C}$ to obtain synthesis gas with the ratio $\mathrm{H}_{2} / \mathrm{CO}=1$. It has been shown that the increased catalytic activity of the nickel sample is provided by an optimal combination of acid-base properties of the surface. It was found that the nickel sample is characterized by the presence of weak acid (electron-acceptor) centers with ionizing force of $9.69 \pm 0.01 \mathrm{eV}$, medium-acid (proton-donor) centers with ionizing force of $10.59 \pm 0.01 \mathrm{eV}$, and weak basic centers capable of ionizing a particle with dissociation constant of $9.89 \pm 0.01$ that distinguish it from other samples.
\end{abstract}

Keywords: biogas, synthesis gas, clinoptilolite, modification, acid-base properties, activity.

doi

\section{Introduction}

One of the most important hydrocarbon conversion reactions is to convert biogas into synthesis gas, which can serve as fuel for fuel cells. Despite numerous studies on catalysts for synthesis gas production from biogas, the problem of creating efficient and thermally stable catalysts with a long lifetime remains relevant [1]. Among the catalysts for this process, the most effective are systems based on nickel and cobalt containing additives of other elements modifiers [2]. In this connection the improvement of catalysts for converting biogas into synthesis gas is moving towards the improvement or replacement of the carrier, of which zeolites have recently attracted special attention [3-6]. Efficient operation of zeolitebased catalysts is ensured by the formation of more hugely dispersed particles of the active component and high oxygen mobility in their lattice [7]. Interest in the use of naturally occurring zeolites is also due to their resistance to sulphatation [8], which is necessary in biogas conversion, as biogas often contains hydrogen sulphide, which is oxidized to $\mathrm{SO}_{2}$ under reaction conditions and promotes sulphatation. In addition, natural zeolites contain alkali and alkali-earth metal oxides, which increase the basicity of the surface, which, according to researchers [9-11], reduces the deposition of carbon-containing compounds. Earlier [12] we showed that zeolite-based catalysts can effectively convert methane into hydrogen gas. However, the question of the optimal acid-base spectrum of the catalyst, the relationship between the nature of the modifier, the acid-base properties of the surface and its activity, remains open. Solution of these issues together is necessary to optimize the chemical composition and properties of the catalyst in order to develop a competitive material.

In this work, we have investigate the effect of the nature of transition metal on the acidbase properties of the surface and the activity of catalysts based on natural clinoptilolite in the reaction of biogas conversion to synthesis gas.

\section{Experimental part}

Clinoptilolite (CL) from the Ai-Dag deposit (Azerbaijan) was used as a catalyst carrier, of the composition (in mass\%): $2.55-\mathrm{Na}_{2} \mathrm{O}$; $1.18 \mathrm{~K}_{2} \mathrm{O}$; $4.05-\mathrm{CaO} ; 0.27-\mathrm{MgO}$ and other oxides ( $\mathrm{SrO}, \mathrm{TiO}_{2}$, etc.) in small concentrations. The catalysts were prepared by the method of 
impregnating the carrier with salts of the corresponding metals ( $\mathrm{Ni}, \mathrm{Co}, \mathrm{Cr}, \mathrm{Mo}, \mathrm{Fe})$ with the calculation of the amount of the active component in the sample 10 mass\% [12]. The acid-base properties were determined by the adsorption of probe molecules (acetone, $n$-butylamine, carbolic acid) using the derivatographic method. For the study of acid centers, probe molecules were chosen that selectively interact with centers of a certain type: acetone only with electron-acceptor centers $(\mathrm{Ei}=9.69 \pm 0.01 \mathrm{eV}) ; n$-butylamine with electron-acceptor and proton-donor $(\mathrm{Ei}=10.59 \pm$ $0.01 \mathrm{eV}$ ) centers. Carbolic acid (phenol) was used to study the basic properties of the samples. The critical diameter of the probe molecules varies in the range of 5.6-7 $\AA$, which prevents them from penetrating into the inner cavity of the zeolite and adsorption occurs on the outer surface.

Before testing, all catalysts were activated in a flow of hydrogen at a rate of $45 \mathrm{ml} / \mathrm{min}$ at a temperature of $400^{\circ} \mathrm{C}$ (5 hours). The amount of catalyst loaded into the vertical quartz reactor was $7 \mathrm{~cm}^{3}$. The temperature was measured in the middle of the catalyst bed with a chromel-alumel thermocouple. To prepare a model gas mixture, natural gas (98\% methane) from the city network and "technical" $\mathrm{CO}_{2}$ from a cylinder were used. The analysis of gaseous products was carried out on an LXM-80 chromatograph. The determination of the catalytic activity was carried out on a laboratory flow-through unit in temperature range 500$800^{\circ} \mathrm{C}$; at the volume ratio of the reacting components $\mathrm{CH}_{4} / \mathrm{CO}_{2}=1: 1$; pressure of 1 atm., volumetric velocity of the gas mixture $500 \mathrm{~h}^{-1}$.

\section{Results and discussion}

Study of the catalytic activity of samples based on clinoptilolite modified with transition metals. The results of testing samples of $\mathrm{Ni}, \mathrm{Co}$, $\mathrm{Fe} / \mathrm{CL}$ catalysts during conversion of biogas to synthesis gas are shown in Figure 1. As can be seen from Figure 1 (a), Fe/CL turned out to be of low activity. The methane $\left(\mathrm{X}_{\mathrm{CH} 4}\right)$ conversion even at $800^{\circ} \mathrm{C}$ was $24 \%$, while the hydrogen yield was $7.9 \%$. There was a strong coke formation on this catalyst was observed, which the authors [13], carrying out the reaction on bulk iron, explained the formation of $\mathrm{FeC}$ and $\mathrm{FeO}$ phases, which shield the active sites of the cata- lyst surface. The conversion of $\mathrm{CH}_{4}\left(\mathrm{X}_{\mathrm{CH} 4}\right)$ and $\mathrm{CO}_{2}\left(\mathrm{X}_{\mathrm{CO} 2}\right)$ significantly increased upon the introducing of cobalt, which reached 96.48 and $95.98 \%$, respectively, at $800^{\circ} \mathrm{C}$ (Figure $1 \mathrm{~b}$ ). However, the most active and stable catalyst was obtained by introducing nickel into the sample (Figure $1 \mathrm{c}$ ). The conversion of $\mathrm{CH}_{4}$ and $\mathrm{CO}_{2}$ on it at a temperature of $700^{\circ} \mathrm{C}$ was maximum (100\%), and the $\mathrm{H}_{2} / \mathrm{CO}$ ratio was equal to 1 , that is necessary to obtain the fuel of the 21 st century - dimethyl ether. In order to relate the nature of the metal component to the activity, chromium and molybdenum-containing samples were prepared, testing of which, as expected, showed their complete passivity.

Thus, it has been established that the activity mainly depends on the nature of the metals introduced. To find out the significant propertyactivity relationships, the acid-base properties of the surface were studied and compared with the activity of the samples. For this purpose, active (Cr, Ni/CL) samples were selected to evaluate the comparative effect of these properties on activity - passive $(\mathrm{Cr}, \mathrm{Mo} / \mathrm{CL})$ samples, and the carrier itself - clinoptilolite.

Study of the acid-base properties of the surface. Initially, the concentration of electronacceptor centers tested with acetone was determined. For a quantitative interpretation of differential thermal analysis results, weight losses of samples in different temperature intervals were calculated (Table). It can be seen from the data obtained that the mass of the samples continuously changes over the entire temperature range. The weight loss in the temperature range $20-120^{\circ} \mathrm{C}$ testifies to the processes of removing physically adsorbed acetone molecules. The analysis of the tabular data shows that $\mathrm{Ni}$ and $\mathrm{Cr}$ containing samples are characterized by the maximum amount of desorbed acetone (0.739 $\mathrm{mmol} / \mathrm{g}$ ). However, although both samples have an endothermic peak at $220^{\circ} \mathrm{C}$, as to the second sample it has a weak intensity compared to the first. Besides, the nickel sample differs by the absence of strong electron-acceptor centers at $440^{\circ} \mathrm{C}$, which is inherent in $\mathrm{Cr} / \mathrm{CL}$, and at 460 and $560^{\circ} \mathrm{C}$, inherent in Mo/CL. The endothermic effect with a maximum at $320^{\circ} \mathrm{C}$, which is noted 
for the nickel sample, shifts by $20^{\circ} \mathrm{C}$ to low temperature field for the cobalt sample and manifests itself at $300^{\circ} \mathrm{C}$. Thus, samples with introduced transition metals are characterized by the appearance of new electron-acceptor centers of various intensities.

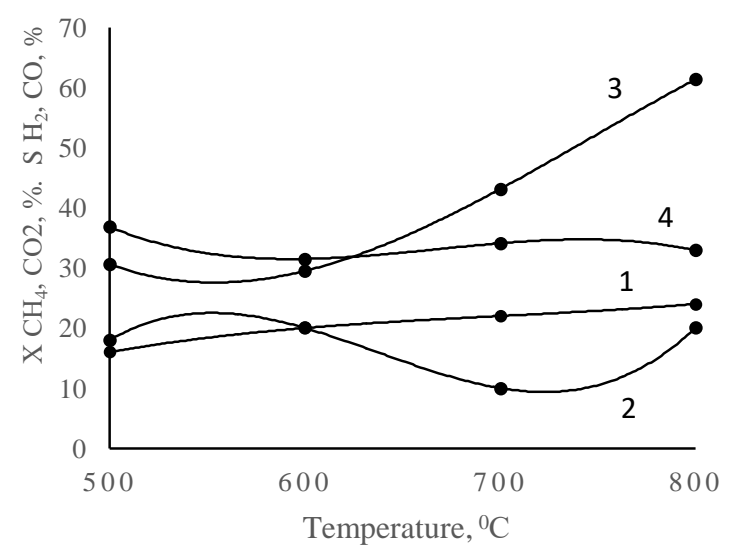

$a$
The concentration of electron acceptor and proton donor centers was tested with a molecule of $n$-butylamine, which has higher ionization energy than acetone. In Figure 2 the sample derivatograms after adsorption of $n$-butylamine are selectively presented.

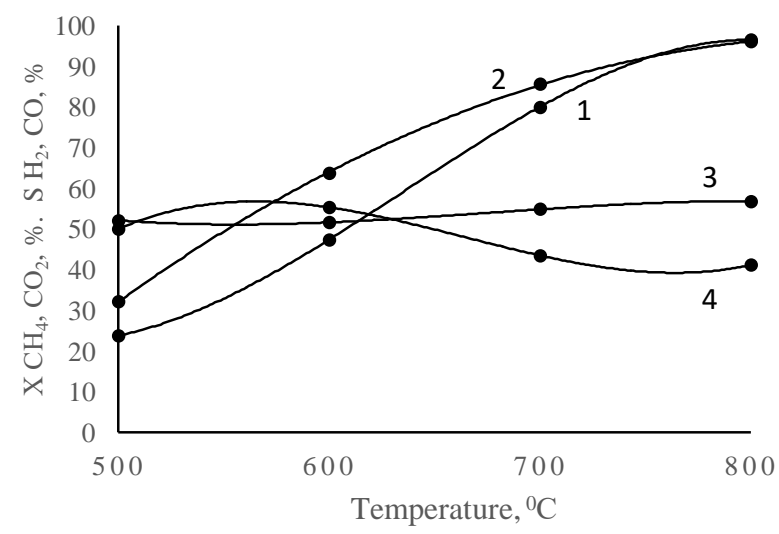

$b$

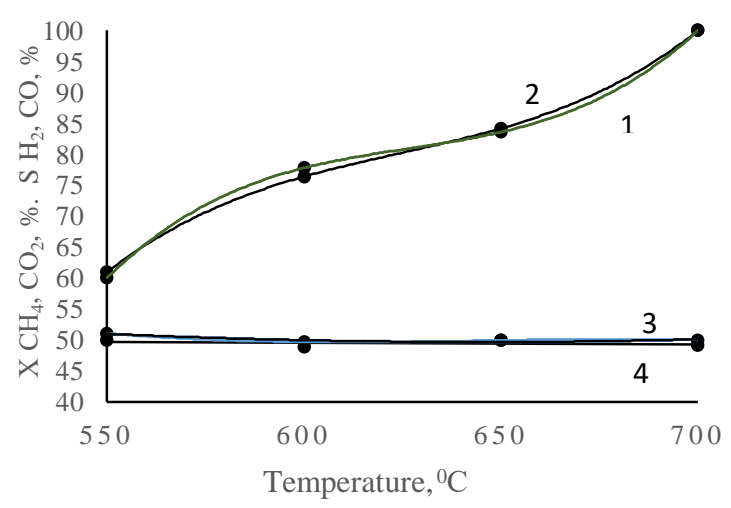

$c$

Fig. 1. Dependence of the degrees of conversions $\left(x_{\mathrm{CH} 4}, \mathrm{CO}_{2}, \%\right) \mathrm{CH}_{4}(I)$ and $\mathrm{CO}_{2}(2)$ and the selectivities of formation $\left(\mathrm{S}_{\mathrm{H} 2 \text {, }}\right.$ $\mathrm{CO}, \%) \mathrm{CO}(3)$ and $\mathrm{H}_{2}(4)$ on temperature at a volume ratio of $\mathrm{CH}_{4} / \mathrm{CO}_{2}=1$ on CL samples of modified: $a-\mathrm{Fe}, b-\mathrm{Co}, c-\mathrm{Ni}$.

Results of thermogravimetric determination of the weight loss of catalyst samples in the temperature range of $20-600^{\circ} \mathrm{C}$ after adsorption of acetone

\begin{tabular}{|c|c|c|c|c|c|}
\hline $\begin{array}{c}\text { Introduced } \\
\text { metal }\end{array}$ & \multicolumn{4}{|c|}{$\frac{\text { Temperature range, }{ }^{0} \mathrm{C} \text { (maximum endothermic effect) }}{\text { weight } \operatorname{loss} \Delta m, \mathrm{mmol} / \mathrm{g}}$} & $\begin{array}{c}\text { Total } \Delta m, \\
\mathrm{mmol} / \mathrm{g}\end{array}$ \\
\hline- & $20-110(110) / 0.123$ & \multicolumn{3}{|c|}{$110-320(320) / 0.308$} & 0.369 \\
\hline Co & $20-100(100) / 0.062$ & $110-300(300) / 0.246$ & \multicolumn{2}{|c|}{$300-440(440) / 0.369$} & 0.431 \\
\hline $\mathrm{Cr}$ & $20-100(100) / 0.123$ & $100-220(220) / 0.369$ & \multicolumn{2}{|c|}{$220-440(440) / 0.554$} & 0.739 \\
\hline Mo & $20-120(120) / 0.246$ & $120-320(320) / 0.554$ & $\begin{array}{c}320-460 \\
(460) / 0.616\end{array}$ & $\begin{array}{c}460-560 \\
(560) / 0.677\end{array}$ & 0.677 \\
\hline $\mathrm{Ni}$ & $20-80(80) / 0.246$ & $80-220(220) / 0.431$ & \multicolumn{2}{|c|}{$220-320(320) / 0.616$} & 0.739 \\
\hline
\end{tabular}


The desorption peaks at 340 and $420^{\circ} \mathrm{C}$, observed only in the nickel sample, and at $360^{\circ} \mathrm{C}$, only in the cobalt sample, characterize the desorption of adsorbed $n$-butylamine from the proton-donor centers of medium strength (Figure 2). The desorption peaks at 480, 500, 540,560 , and $600^{\circ} \mathrm{C}$ are most likely associated with the desorption of adsorbed $n$-butylamine molecules associated with strong electronacceptor centers on the sample surface. Exothermic effects on the DTA curves at 360$440^{\circ} \mathrm{C}$ are likely to characterize the partial oxidation of weakly bound adsorbed molecules. Attention is drawn to the sharp character of the DTA curve of the nickel sample, that distinguishes it from others, and the peak is observed at $440^{\circ} \mathrm{C}$, which is also characteristic only for this sample. The maximum amount of the total desorbed $n$-butylamine is observed in the $\mathrm{Ni}$ sample $(1.47 \mathrm{mmol} / \mathrm{g})$, the smallest - in Co $(0.146 \mathrm{mmol} / \mathrm{g})$, in the rest it changes in the range $0.538-0.685 \mathrm{mmol} / \mathrm{g}$. Thus, on the surface of the samples with introduced metals, there are stronger centers capable of interacting with the $n$-butylamine molecule.

The basic properties of the samples were studied by the adsorption of phenol molecules. Figure 3 selectively shows the derivatograms of the samples after the adsorption of phenol molecules. The desorption curve of the nickel sample shows a peak at $220^{\circ} \mathrm{C}$, which is absent on other samples and characterizes weakly bonded phenol molecules. On other samples this peak is shifted to the high temperature region and manifests itself: at 260 cobalt, molybdenum and chromium, respectively, at 300 and $380^{\circ} \mathrm{C}$.

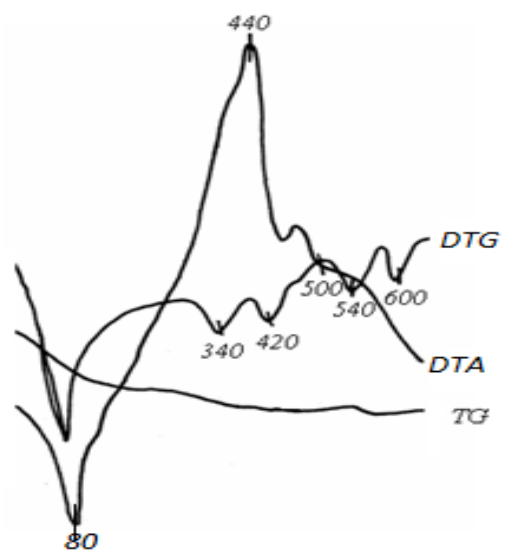

$a$

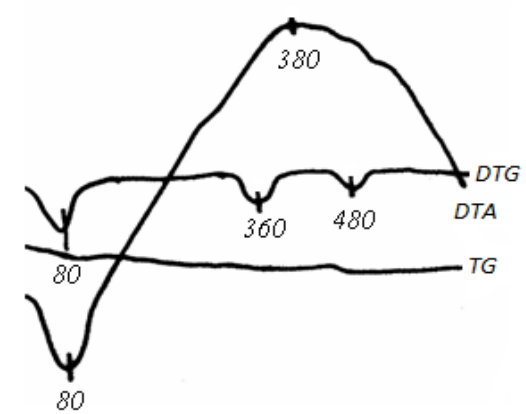

$b$

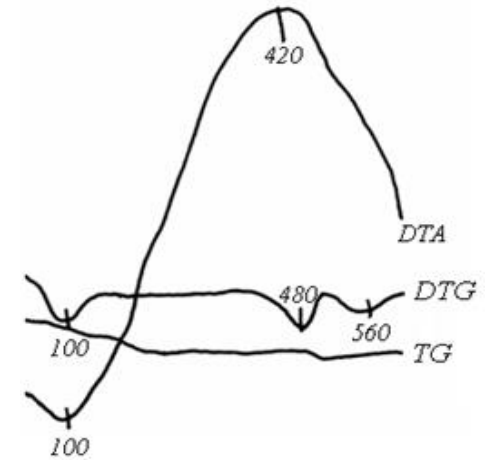

c

Fig. 2. Derivatograms taken after adsorption of $n$-butylamine by catalyst samples with introduced metals: $a-\mathrm{Ni}, b-$ $\mathrm{Co}, c-\mathrm{Cr}$.

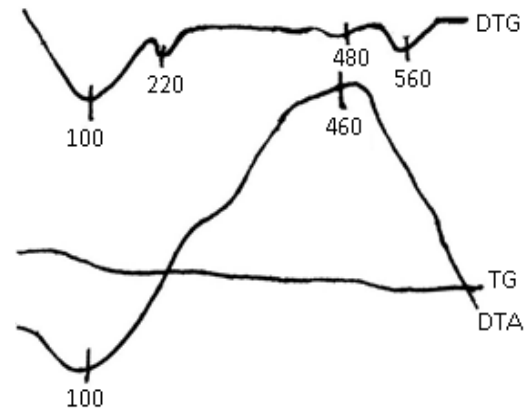

$a$

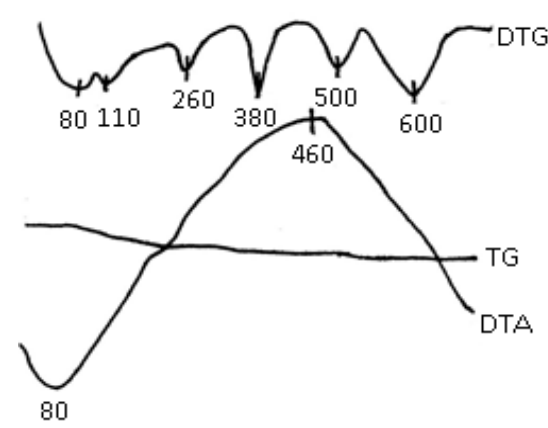

$b$

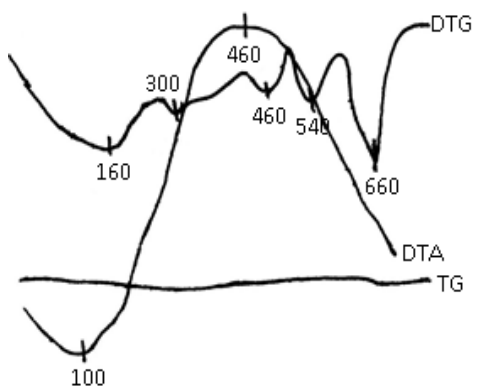

$c$

Fig. 3. Derivatograms of samples with introduced metals: $a-\mathrm{Ni}, b-\mathrm{Co}, c-\mathrm{Cr}$ after phenol adsorption. 
The cobalt sample, unlike the nickel sample, is characterized by desorption peaks at 260 and $380^{\circ} \mathrm{C}$. Desorption peaks at $300-380^{\circ} \mathrm{C}$ apparently, correspond to centers of medium strength, while peaks in the temperature range $460-660^{\circ} \mathrm{C}$ characterize strong basic centers on the surface of the samples. Strong desorption peaks at $660^{\circ} \mathrm{C}$ are only present on chromiumand molybdenum containing samples. The cobalt-containing sample has a desorption peak at $600^{\circ} \mathrm{C}$, while the nickel sample has no strong peaks at 600 and $660^{\circ} \mathrm{C}$. The results of calculating the total mass loss at heating samples with introduced metals without taking into account physically adsorbed molecules showed that the total mass loss (in the temperature range of 120 $600^{\circ} \mathrm{C}$ ) makes ap: $\mathrm{Co}-0.151 ; \mathrm{Ni}-0.158$ $\mathrm{mmol} / \mathrm{g}$, and for Mo and $\mathrm{Cr} 0.186$ and 0.217 $\mathrm{mmol} / \mathrm{g}$ respectively. The DTA curve of all samples is characterized by a single exothermic effect with a maximum at $460^{\circ} \mathrm{C}$, that is connected to partial oxidation of weakly bound phenol molecules on the surface of the samples.

So, a study of sample activity in the reaction of biogas conversion to synthesis gas revealed that the highest activity and selectivity is observed on the nickel sample.

The temperature at which full conversion is achieved on this sample is reached at $700^{\circ} \mathrm{C}$ (at a volumetric feed rate of $500 \mathrm{~h}^{-1}$ ), on a cobalt sample under the same process conditions the maximum methane conversion $(96.48 \%)$ is observed at $800^{\circ} \mathrm{C}$.

A comparative study of the acidic properties of the sample surface showed that a nickelcontaining sample is characterized by the existence on its surface of weak electron-acceptor centers (at $220^{\circ} \mathrm{C}$ with a concentration of 0.431 $\mathrm{mmol} / \mathrm{g}$ ), capable of ionizing a molecule with a force of $9.69 \pm 0.01 \mathrm{eV}$, and lack of strong centers. Such weak electron-acceptor centers (at 2200C) existed on the surface of an inactive chromium-containing sample, however, of a relatively low intensity (concentration $0.369 \mathrm{mmol} / \mathrm{g}$ ), and this sample was also characterized by the presence of strong electron-acceptor centers $\left(440^{\circ} \mathrm{C}\right)$, which is absent in the nickel sample. The molybdenum-containing sample also had strong electron-acceptor centers. The cobalt-containing sample showing relatively low activity contained electron-acceptor centers with an ionizing force of $9.69 \pm 0.01 \mathrm{eV}$, which gave off the adsorbed particle at $300^{\circ} \mathrm{C}$, and strong electron-acceptor centers also existed on the surface.

Comparative assessment of acid centers of another type (have been determined using $n$ butylamine) exposed that on the active catalysts a number of medium strength proton-donor and electron-acceptor centers with ionizing capacity $10.59 \pm 0.01 \mathrm{eV}$, and on the nickel sample particle interacting with these centers was desorbed at 340 and $420^{\circ} \mathrm{C}$, while the cobalt sample is slightly higher - at 360 and $480^{\circ} \mathrm{C}$. On non-active samples (chromium and molybdenum), medium strength acid centers were absent.

Comparative assessment of basic centers on the sample surface showed that the concentration of basic centers capable of ionizing a particle with dissociation constant $9.89 \pm 0.01$ is the smallest on the nickel sample, and there are weak basic centers on the surface from which adsorbed particles are desorbed at $220^{\circ} \mathrm{C}$, while on other samples of catalysts these centers are absent.

Thus, the distinctive feature of the nickel sample is the presence of weak acid (electronacceptor) centers with an ionizing force of $9.69 \pm 0.01 \mathrm{eV}$, medium-power acid (proton-donor) centers with an ionizing force of $10.59 \pm 0$. $01 \mathrm{eV}$, and weak basic centers capable of ionizing a particle with dissociation constant $9.89 \pm 0.01$, which promotes the manifestation of high activity of the sample in the reaction of biogas conversion into synthesis gas (complete methane conversion is observed at $700^{\circ} \mathrm{C}, \mathrm{CH}_{4} / \mathrm{CO}_{2}=1: 1$, pressure $1 \mathrm{~atm}$, volume velocity of the gas mixture $500 \mathrm{~h}^{-1}$ ).

\section{References}

1. Krylov O.V. Kataliz v 2004 g. K itogam XIII Mezhdunarodnogo kongressa po katalizu. Parizh, 10-15 iyulya, 2004. Kinetika i kataliz. 2005. № 3. T. 46. S. 474-480.

2. Arutyunov V.S. K itogam 7-go mezhdunarodnogo simpoziuma po konversii prirodnogo gaza (NGCS7). Kataliz v promyshlennosti. 2004. № 5. S. 54-59.

3. Antonio N. Pinheiro, Antoninho Valentini, José M. Sasaki, Alcineia C.Oliveira Highly stable dealuminated zeolite support for the production of hydrogen by dry reforming of methane. Appl. Catalysis A: General. 2009. V. 355. Issues 1-2. P. 156-168. 
4. Khallish D., Sherifi O., Ben-Taarit O., Oru A. Riforming metana pod deystviyem dioksida ugleroda na tseolitnykh katalizatorakh, soderzhashchikh obmennyye kationy nikelya. Kinetika i kataliz. 2008. № 5. T. 49. S. 698-706.

5. Zhang W.D., Liu B.S., Zhu C., Tian Y.L. Preparation of $\mathrm{La}_{2} \mathrm{NiO}_{4} / \mathrm{ZSM}-5$ catalyst and catalytic performance in $\mathrm{CO}_{2} / \mathrm{CH}_{4}$ reforming to syngas. Appl. Catal. A. 2005. V. 292. P. 138-143.

6. Izquierdo U., Barrio V.L., Bizkarra K.. Ni and Rh$\mathrm{Ni}$ catalysts supported on Zeolites L for hydrogen and syngas production by biogas reforming processes. Chem. Eng. J. 2013. 238. P. 178-188.

7. Vishnetskaya M.V., Yemel'yanov A.N., Shcherbakov N.V. Rol singletnogo kisloroda v kataliticheskikh prevrashcheniyakh uglevodorodov. Zhurn. fiz. khimii. 2004. № 5. C. 40-43.

8. Mukhlenov I.P. Tekhnologiya katalizatorov. L.: Khimiya, 1989. $272 \mathrm{~s}$.

9. Zahra Alipour, Mehran Rezaei, Fereshteh Meshkani Effect of alkaline earth promoters $(\mathrm{MgO}, \mathrm{CaO}$, and $\mathrm{BaO}$ ) on the activity and coke formation of $\mathrm{Ni}$ catalysts supported on nanocrystalline $\mathrm{Al}_{2} \mathrm{O}_{3}$ in dry re- forming of methane. J. Ind. Eng. Chem. 2014. V. 20. Issue 5. P. 2858-2863.

10. Hou Z., Yokota O., Tanaka T., Yashima T. Characterization of $\mathrm{Ca}$-promoted $\mathrm{Ni} / \alpha-\mathrm{Al}_{2} \mathrm{O}_{3}$ catalyst for $\mathrm{CH}_{4}$ reforming with. Appl. Catal. A. 2003. No 2. P. 381-387.

11. Solovyev S.A., Zatelepa R.N., Gubaren Ye.V., Strizhak P.Ye., Moroz E.M. Vliyaniye dobavok oksidov shchelochnykh metallov (K2O, Na2O, Li2O) na aktivnost' i stabil'nost' raboty $\mathrm{Ni} / \mathrm{Al} 2 \mathrm{O} 3$ katalizatorov $\mathrm{v}$ protsesse uglekislotnoy konversii metana. Z. prikl. khimii. 2007. T. 80. № 11. S. 1858-1863.

12. Dzhafarova S.T., Abbasova N.I., Akhmedov M.M. Ispol'zovaniye prirodnogo tseolita - klinoptilolita dlya sozdaniya katalizatorov uglekislotnoy konversii metana $\mathrm{v}$ sintez-gaz. Khim. prom-st' segodnya. 2010. № 1. S. 9-13.

13. Galaktionova L.V., Arkatova L.A., Kurina L.N. Fesoderzhashchiye intermetallidy kak katalizatory uglekislotnoy konversii metana. Zhurn. fiz. khimii. 2008. T. 82. № 2. S. 271-275.

\section{KEÇID METALLARININ TəBİĐTININ TəBIII KLINOPTILOLIT OSASINDA HAZIRLANMIŞ KATALIZATORLARIN SOTHLORININ TURŞU-OSASI XÜSUSIYYYTLORINઇ Və BIOOQAZIN SINTEZ- QAZA KONVERSIYA REAKSIYASINDA AKTIVLIKLORINO TOSIRI}

\section{S.T.Cəfərova}

Bioqazın sintez-qaza konversiya reaksiyasında, keçid metalları (Ni, Co, Cr, Mo, Fe) ilə modifikasiya edilmiş təbii klinoptilolit əsasında hazırlanmış katalizatorlar tədqiq edilmişdir. Osas diqqət turşu-əsasi səth xüsusiyyətləri ilə aktivlik arasındakı əlaqənin müəyyənləşdirilməsinə yetirilmişdir. Bu, tətbiq olunan keçid metalının təbiətinin turşu-əsasi spektrinə təsirini öyrənmək və əldə edilmiş məlumatları nümunələrin aktivlikləri ilə müqayisə etməklə əldə edilmişdir. Bir nikel nümunəsinin ən yüksək aktivliyi və seçiciliyi müəyyən edilmişdir ki, bu da metanın $700^{\circ} \mathrm{C}-\mathrm{d} ə \mathrm{H}_{2} / \mathrm{CO}=1$ nisbətində sintez qazı əldə etməklə tam çevrilməsinə imkan verir. Nikel nümunəsinin artan katalitik aktivliyinin turşuəsasi səth xüsusiyyətlərinin optimal birləşməsi ilə təmin olunduğu göstərilmişdir. Müəyyən edilmişdir ki, nikel nümunəsi digər nümunələrdən fərqləndirən ionlaşma gücü $9.69 \pm 0.01 \mathrm{eV}$ olan zəif turşu (elektron-akseptor) mərkəzlərin, ionlaşdırma qüvvəsi $10.59 \pm 0.01 \mathrm{eV}$ olan orta güclü (proton-donor) turşu mərkəzlərin və $9.89 \pm 0.01$ ayrılma sabitliyi ilə hissəcik ionlaşdırmağa qadir olan zəif əsas mərkəzlərin olması ilə xarakterizə olunur.

Açar sözlor: bioqaz, sintez-qaz, klinoptilolit, modifikasiya, turşu-əsasi xüsusiyyətləri, aktivlik.

\section{ВЛИЯНИЕ ПРИРОДЫ ПЕРЕХОДНОГО МЕТАЛЛА НА КИСЛОТНО-ОСНОВНЫЕ СВОЙСТВА ПОВЕРХНОСТИ И АКТИВНОСТЬ КАТАЛИЗАТОРОВ НА ОСНОВЕ ПРИРОДНОГО КЛИНОПТИЛОЛИТА В РЕАКЦИИ КОНВЕРСИИ БИОГАЗА В СИНТЕЗ-ГАЗ}

\section{С.Т.Джафарова}

В реакции конверсии биогаза в синтез-газ исследованы катализаторы на основе природного клиноптилолита, модифицированного переходными металлами ( $\mathrm{Ni}, \mathrm{Co}, \mathrm{Cr}, \mathrm{Mo}, \mathrm{Fe})$. Основное внимание уделено выявлению связи кислотно-основные свойства поверхности-активность. Это достигнуто путем изучения влияния природы введенного переходного металла на кислотно-основной спектр и сопоставление полученных данных с активностью образцов. Установлена наибольшая активность и селективность никелевого образца, позволившего достигать полной конверсии метана при $700^{\circ} \mathrm{C}$ с получением синтез-газа с соотношением $\mathrm{H}_{2} / \mathrm{CO}=1$. Показано, что повышенная каталитическая активность никелевого образца обеспечивается оптимальным сочетанием кислотных и основных свойств поверхности. Установлено, что никелевый образец характеризуется наличием слабых кислотных (электроно-акцепторных) центров с ионизирующей силой $9.69 \pm 0.01 э \mathrm{~B}$, среднесильных кислотных (протонодонорных) центров с ионизирующей силой $10.59 \pm 0.01 э \mathrm{~B}$ и

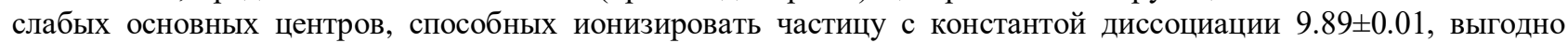
отличающим его от других образцов.

Ключевье слова: биогаз, синтез-газ, клиноптилолит, модификаџия, кислотно-основные свойства, активность. 